\title{
Plasma amino acids and tissue methionine levels in fruit bats (Rousettus aegyptiacus) with nitrous oxide-induced vitamin $\mathrm{B}_{12}$ deficiency
}

\author{
BY JUSTIN VAN DER WESTHUYZEN ${ }^{1}$, SUSAN V. VAN TONDER ${ }^{1}$, \\ JAYNE E. GIBSON ${ }^{1}$, TERENCE A. KILROE-SMITH ${ }^{2}$ AND JACK METZ1 \\ ${ }^{1}$ Department of Haematology, School of Pathology of the South African Institute for \\ Medical Research, and the University of the Witwatersrand, POBox 1038, \\ Johannesburg 2000, South Africa \\ ${ }^{2}$ National Centre for Occupational Health, Johannesburg, South Africa
}

(Received 31 July 1984 - Accepted 21 December 1984)

1. The effect of methylcobalamin inactivation by the gas nitrous oxide on plasma amino acid and tissue methionine levels in fruit bats (Rousettus aegyptiacus) was examined.

2. Animals exposed to $\mathrm{N}_{2} \mathrm{O}$-oxygen $(1: 1, \mathrm{v} / \mathrm{v})$ for $90 \mathrm{~min}$ daily received a fruit diet with or without methionine or betaine supplements. Exposure and diets were continued for up to 17 weeks or until neurological impairment and muscular weakness was established.

3. All the groups exposed to $\mathrm{N}_{2} \mathrm{O}$ had significantly lower liver, brain and plasma methionine concentrations except the methionine-supplemented animals which showed significantly raised levels. Plasma homocysteine, which was absent in controls, was present in all the $\mathrm{N}_{2} \mathrm{O}$-exposed groups.

4. Betaine supplementation resulted in reduced accumulation of homocysteine in plasma. However, plasma and liver methionine levels were only slightly increased compared with animals on the basal diet, and brain methionine levels were the lowest of all the groups studied.

5. These results support the hypothesis that reduced methionine synthesis is an important contributor to the development of neurological impairment in this species and suggest that dietary supplementation with the methionine precursor betaine cannot replace the loss of vitamin $\mathbf{B}_{12}$-dependent methionine synthesis.

The anaesthetic gas nitrous oxide reacts with transition metal complexes in solution, including the cobalt-containing vitamin, vitamin $\mathrm{B}_{12} . \mathrm{N}_{2} \mathrm{O}$ oxidizes active reduced $\operatorname{cob}(\mathrm{I})$ alamin to the inactive cob(III)alamin (Banks et al. 1968) resulting in the inhibition of the vitamin $\mathrm{B}_{12}$-dependent enzyme 5-methyltetrahydrofolate homocysteine methyltransferase (methionine synthase; EC 2.1.1.13) (Deacon et al. 1980). The activity of the methionine synthase enzyme is markedly reduced in rat liver after only 30 min exposure to $\mathrm{N}_{2} \mathrm{O}$ and declines steadily thereafter (Deacon et al. 1978; Kondo et al. 1981). Chronic exposure of the fruit bat (Rousettus aegyptiacus) to $\mathrm{N}_{2} \mathrm{O}$ for 12-14 weeks reduced methionine synthase activity in the liver to only 5\% that of controls (S. V. van Tonder, A. Ruck, J. van der Westhuyzen, F. Fernandes-Costa and J. Metz, unpublished results).

The mechanism whereby vitamin $B_{12}$ deficiency leads to neurological impairment, whether produced by dietary restriction or inactivation of methylcobalamin by $\mathrm{N}_{2} \mathrm{O}$, is unknown. The fruit bat Rousettus provides a small-animal model for the study of this mechanism, as chronic exposure to $\mathrm{N}_{2} \mathrm{O}$ leads to neurological impairment, ataxia and death in this species (van der Westhuyzen et al. 1982). The provision of methionine for the nervous system appears to be crucial, as supplementation of the diet with methionine significantly delays the onset of ataxia and death in bats chronically exposed to $\mathrm{N}_{2} \mathrm{O}$ (van der Westhuyzen et al. 1982). Tissues other than those of the nervous system have an additional, non-vitamin $\mathrm{B}_{12}$-dependent pathway for methionine synthesis, catalysed by the enzyme betaine homocysteine methyltransferase (EC 2.1.1.5) (Sturman et al. 1976). Supplementation of the diet with betaine also delays the onset of ataxia and death in bats exposed to $\mathrm{N}_{2} \mathrm{O}$, but is far less effective than methionine itself (van der Westhuyzen \& Metz, 1984). 
We have studied the concentrations of amino acids in the plasma and methionine in the brain and liver in bats with $\mathrm{N}_{2} \mathrm{O}$-induced neurological impairment to obtain more information on the interrelations between amino acids and cobalamin metabolism. The effect of supplementation of the diet with methionine or betaine was also evaluated.

\section{METHODS \\ Experimental animals and diets}

Cape fruit bats (Rousettus aegyptiacus) were captured in the wild and maintained in vivaria on a pest-free, all-fruit diet consisting mainly of bananas and papayas (paw-paw) as described previously (van der Westhuyzen et al. 1983). A multivitamin preparation lacking vitamin $\mathbf{B}_{12}$ (Abidec; Parke-Davis, Cape Town) was given fortnightly (van der Westhuyzen et al. 1983). Normal vitamin $B_{12}$ status was maintained in control animals by the fortnightly injection of $5 \mu \mathrm{g}$ cyanocobalamin $/ \mathrm{kg}$ body-weight.

Two separate series of experiments were undertaken. In the first series, in which plasma amino acid levels were studied, supplementation of the diet with methionine or betaine was of the order of $0.4-0.55 \mathrm{mg} / \mathrm{kg}$ body-weight. In the experiments in which tissue methionine levels were measured, the amount of the supplement was increased about threefold.

At the start of the experiment, cyanocobalamin supplementation was discontinued and $\mathrm{N}_{2} \mathrm{O}$ was administered to animals randomly allocated to the following dietary groups: (a) $\mathrm{N}_{2} \mathrm{O}$ group: standard all-fruit diet. (b) $\mathrm{N}_{2} \mathrm{O}$ /methionine group: fruit diet supplemented with L-methionine ( $99 \%$; Riedel-de Haën, Germany) in the proportions 0.6 or $2 \mathrm{~g} / \mathrm{kg}$ fruit. This supplied approximately 60 or $200 \mathrm{mg}$ methionine/animal per $\mathrm{d}(0.55$ or $1.3 \mathrm{~g} / \mathrm{kg}$ bodyweight respectively). (c) $\mathrm{N}_{2} \mathrm{O}$ /betaine group: fruit supplemented with betaine (Sigma Chemical Co., St Louis, MO) in the proportions 0.5 or $2 \mathrm{~g} / \mathrm{kg}$ fruit, supplying approximately 50 or $200 \mathrm{mg}$ betaine/animal per $\mathrm{d}(0.4$ or $1.3 \mathrm{~g} / \mathrm{kg}$ body-weight respectively).

\section{Exposure to $\mathrm{N}_{2} \mathrm{O}$}

Test animals were exposed to an atmosphere of $\mathrm{O}_{2}-\mathrm{N}_{2} \mathrm{O}(50: 50, \mathrm{v} / \mathrm{v})$ daily for $90 \mathrm{~min}$ in a specially constructed cabinet in which levels of water vapour and carbon dioxide were controlled. The bats spent the remainder of the $24 \mathrm{~h}$ in their usual cages. Exposure was continued until neurological impairment and muscular weakness was established or, in the case of some of the methionine-supplemented bats, until 17 weeks had elapsed.

\section{Plasma amino acid determination}

At the conclusion of the experiment blood was drawn by cardiac puncture into heparinized syringes and the plasma separated and stored at $-20^{\circ}$ until assayed. All samples were collected in the morning between 09.00 and 11.00 hours, which was approximately $4.5-6.5 \mathrm{~h}$ postprandial. Plasma proteins were precipitated with $50 \mathrm{mg}$ salicylsulphonic acid/ml plasma, and the samples analysed on a Durrum D500 automatic amino acid analyser (San Francisco, CA). The standard step-wise, five buffer, physiological 310 min programme was employed (Lee, 1974).

\section{Tissue methionine assay}

Animals were killed by exsanguination. The liver and brain were removed rapidly, weighed, homogenized briefly in 4 vol. phosphate-buffered saline $(9 \mathrm{~g}$ sodium chloride $/ \mathrm{l}$; brain, $2 \mathrm{vol}$.), and boiled for $5 \mathrm{~min}$ to destroy proteolytic enzymes. The extracts were rehomogenized and stored at $-20^{\circ}$ until assayed. In order to obtain sufficient material for assay, brain extracts from two animals were pooled. 
Table 1. Tissue methionine concentrations in control and nitrous oxide-exposed bats (Rousettus aegyptiacus) receiving dietary supplements

(Mean values with their standard errors)

\begin{tabular}{|c|c|c|c|c|c|c|}
\hline \multirow[b]{3}{*}{ Group } & \multicolumn{6}{|c|}{ Methionine $(\mu \mathrm{g} / \mathrm{g}$ tissue) } \\
\hline & \multicolumn{3}{|c|}{ Liver } & \multicolumn{3}{|c|}{ Brain } \\
\hline & Mean & $\mathrm{SE}$ & $n \neq$ & Mean & SE & $n \ddagger$ \\
\hline Controls & 24.9 & $3 \cdot 5$ & 6 & 8.4 & 0.7 & 3 \\
\hline $\mathrm{N}_{2} \mathrm{O}$ only & $13 \cdot 5^{*}$ & $1 \cdot 6$ & 6 & $4 \cdot 5^{*}$ & 0.9 & 3 \\
\hline $\mathrm{N}_{2} \mathrm{O} /$ betaine $(2 \mathrm{~g} / \mathrm{kg}$ fruit) & $16 \cdot 7^{*}$ & 0.8 & 5 & $2 \cdot 4^{*}$ & $1 \cdot 0$ & 2 \\
\hline $\mathrm{N}_{2} \mathrm{O} /$ methionine $(2 \mathrm{~g} / \mathrm{kg}$ fruit) & $>120^{* *+\dagger}$ & & $2 \S$ & $>58^{* *+\dagger}$ & & 1 \\
\hline
\end{tabular}

Mean values were significantly different from those of the controls: ${ }^{*} P<0.05, * * P<0.01$.

Mean values were significantly different from those for the $\mathrm{N}_{2} \mathrm{O}$ group; $\uparrow \uparrow P<0.01$.

$\ddagger$ No. of samples analysed. Brain samples were pooled from two animals.

$\S$ Four of the six bats in the group died prematurely as reported previously (van der Westhuyzen \& Metz, 1984).

Tissue methionine concentrations were determined by microbiological assay. All samples were assayed in a single batch to avoid batch-to-batch variations. Before assay, homogenate equivalent to $2 \mathrm{~g}$ liver or $4 \mathrm{~g}$ brain was made up to $20 \mathrm{ml}$ with $0.1 \mathrm{M}$-sodium phosphate buffer (pH 5.7) and deproteinized by heating at $69 \mathrm{kPa}$ pressure for $10 \mathrm{~min}$. The supernatant volume was readjusted to $20 \mathrm{ml}$ and neutralized to $\mathrm{pH} 7$. Duplicate $5 \mathrm{ml}$ portions were assayed (with a third serving as a blank) for methionine using Leuconostoc mesenteroides (ATCC 8042) as the test organism.

\section{Statistical analyses}

Statistical analyses were performed using Student's $t$ test (two-tailed). The level of significance was chosen as $P<0.05$.

\section{RESULTS}

Tissue methionine concentration (Table 1)

All the groups exposed to $\mathrm{N}_{2} \mathrm{O}$ had significantly lower mean liver and brain methionine levels, except the methionine-supplemented animals which exhibited greatly raised methionine concentrations. (The number of bats in the $\mathrm{N}_{2} \mathrm{O}$ /methionine group was reduced from six to two by sudden, unexpected deaths as observed previously in $\mathrm{N}_{2} \mathrm{O}$-exposed animals .receiving relatively high doses of methionine (van der Westhuyzen et al. 1982; van der Westhuyzen \& Metz, 1984)).

Although the liver methionine level of the $\mathrm{N}_{2} \mathrm{O}$ /betaine group was higher than the $\mathrm{N}_{2} \mathrm{O}$ group on the basal diet, and the brain methionine level somewhat lower, these differences were not statistically significant.

\section{Plasma amino acid levels (Table 2)}

Compared with control animals, plasma methionine levels were significantly lower in the $\mathrm{N}_{2} \mathrm{O}$ and $\mathrm{N}_{2} \mathrm{O}$ /betaine groups and significantly higher in the $\mathrm{N}_{2} \mathrm{O} /$ methionine group. Plasma homocysteine, which was absent in control animals, was present in all the $\mathrm{N}_{2} \mathrm{O}$-exposed groups. The level of lysine was also higher in all the $\mathrm{N}_{2} \mathrm{O}$ groups. Other differences are listed in Table 2 and are discussed later (p. 661). 
Table 2. Plasma amino acids and urea (umol/l) in control and nitrous oxide-exposed bats (Rousettus aegyptiacus) receiving dietary supplements

(Mean values with their standard errors)

\begin{tabular}{|c|c|c|c|c|c|c|c|c|}
\hline \multirow[t]{2}{*}{ Group ... } & \multicolumn{2}{|c|}{$\begin{array}{l}\text { Controls } \\
(n 6)\end{array}$} & \multicolumn{2}{|c|}{$\begin{array}{l}\mathrm{N}_{2} \mathrm{O} \text { only } \\
\quad(n 5)\end{array}$} & \multicolumn{2}{|c|}{$\begin{array}{c}\mathrm{N}_{2} \mathrm{O} / \text { methionine } \\
(\text { (n } 6)\end{array}$} & \multicolumn{2}{|c|}{$\begin{array}{c}\mathrm{N}_{2} \mathrm{O} / \text { betaine } \ddagger \\
(n 5)\end{array}$} \\
\hline & Mean & $\mathbf{S E}$ & Mean & $\mathrm{SE}$ & Mean & SE & Mean & $\mathrm{SE}$ \\
\hline Taurine & 63 & 9 & 88 & 7 & $122^{* * *}$ & 8 & 52 & 6 \\
\hline Threonine & 164 & 18 & $275^{* * *}$ & 19 & 164 & 42 & $226^{*}$ & 21 \\
\hline Serine & 150 & 14 & $313^{* * *}$ & 12 & 244 & 47 & $311^{* * *}$ & 25 \\
\hline Glutamate & 200 & 23 & 184 & 21 & 225 & 23 & 246 & 48 \\
\hline Glutamine & 1442 & 170 & 1222 & 121 & 1138 & 102 & 1240 & 147 \\
\hline Proline & 34 & 4 & 25 & 3 & 51 & 5 & 34 & 6 \\
\hline Glycine & 345 & 33 & $478^{*}$ & 45 & $168^{* *}$ & 37 & 372 & 21 \\
\hline Alanine & 231 & 18 & 239 & 22 & 491 & 123 & 290 & 42 \\
\hline Citrulline & 45 & 4 & 41 & 4 & $28^{*}$ & 6 & $33^{*}$ & 2 \\
\hline Valine & 827 & 138 & 888 & 56 & 569 & 109 & 1103 & 234 \\
\hline Cysteine & 59 & 4 & $28 * * *$ & 4 & 46 & 2 & 44 & 5 \\
\hline Methionine & 30 & 3 & $13^{* * *}$ & 1 & $191^{* *}$ & 47 & $19 * *$ & 4 \\
\hline Isoleucine & 196 & 26 & $274^{*}$ & 10 & 111 & 24 & 283 & 45 \\
\hline Leucine & 315 & 25 & $476^{* *}$ & 28 & 323 & 62 & 510 & 102 \\
\hline Tyrosine & 48 & 4 & $78^{* *}$ & 4 & 49 & 11 & 69 & 11 \\
\hline Phenylalanine & 109 & 11 & 213 & 45 & 76 & 14 & 106 & 14 \\
\hline Homocysteine & ND & & $58^{* * *}$ & 3 & $41^{* *}$ & 11 & $20^{* * *}$ & 4 \\
\hline Trytophan & 47 & 12 & 52 & 9 & $10^{*}$ & 3 & 49 & 4 \\
\hline Ornithine & 104 & 12 & 161 & 23 & 105 & 20 & $159 * *$ & 8 \\
\hline Lysine & 175 & 24 & $379^{* *}$ & 55 & $294^{*}$ & 28 & $285^{*}$ & 35 \\
\hline Histidine & 250 & 35 & $372^{*}$ & 22 & 425 & 162 & 302 & 35 \\
\hline Arginine & 94 & 11 & $149 *$ & 20 & $191^{* *}$ & 20 & 134 & 14 \\
\hline Urea & 2408 & 285 & 2245 & 143 & 1604 & 412 & 2155 & 391 \\
\hline
\end{tabular}

ND, not detectable.

Mean values were significantly different from those for control values: ${ }^{*} P<0.05,{ }^{* *} P<0.01,{ }^{* * *} P<0 \cdot 001$. $+0.6 \mathrm{~g}$ methionine $/ \mathrm{kg}$ fruit.

$\$ 0.5 \mathrm{~g}$ betaine $/ \mathrm{kg}$ fruit.

\section{DISCUSSION}

Because of the important role methionine appears to play in the nervous system, tissue and plasma methionine levels were investigated in control and methylcobalamin-inactivated bats with neurological impairment. Previously we had confirmed the findings of Scott et al. (1981) in monkeys when we showed that supplementation of the diet with methionine significantly protected fruit bats from $\mathrm{N}_{2} \mathrm{O}$-induced neurological impairment (van der Westhuyzen et al. 1982). Since $\mathrm{N}_{2} \mathrm{O}$ inhibits the methylcobalamin-dependent methionine synthase reaction, it was not unexpected to find significantly lower levels of methionine in the brain and liver of $\mathrm{N}_{2} \mathrm{O}$-exposed animals. Supplementation of the diet with methionine resulted in greatly raised levels of this amino acid in tissues and plasma. Dietary supplementation with the methionine precursor betaine, even at the level of $2 \mathrm{~g} / \mathrm{kg}$ food, only slightly raised the liver methionine concentration of $\mathrm{N}_{2} \mathrm{O}$-exposed animals, while the brain concentration was the lowest recorded in the present study. This confirms the absence of the betaine-homocysteine methyltransferase enzyme in the brain (Lumb et al. 1983). The ratio, brain: liver methionine concentration was similar in unsupplemented $\mathrm{N}_{2} \mathrm{O}$ and control animals. However, when betaine was added to the diet of $\mathrm{N}_{2} \mathrm{O}$-exposed bats, the ratio was markedly decreased, confirming the presence of betaine-dependent methionine synthesis in liver but not in brain. The lower liver methionine levels in bats receiving betaine compared with 
control animals indicates that betaine-dependent methionine synthesis in non-nervous tissue of the bat cannot fully substitute for the loss in activity of the methylcobalamin-dependent methionine synthase reaction.

In an earlier study, we showed that supplementation of the diet with betaine delayed the onset of neurological impairment in $\mathrm{N}_{2} \mathrm{O}$-exposed bats (van der Westhuyzen \& Metz, 1984). However, betaine was considerably less effective in preventing weight loss and delaying the onset of impairment than corresponding levels of methionine as a dietary supplement. The methionine levels in the brain at death were lowest in the betaine-supplemented animals, despite the partially protective effect of betaine on the development of neurological impairment (van der Westhuyzen \& Metz, 1984). This observation suggests that the $\mathrm{N}_{2} \mathrm{O}$-induced neuropathy is not directly related to the concentration of methionine per se in the central nervous system. The protective effect of methionine must be exerted via some other mechanism, possibly the provision of additional formate groups, as suggested by Chanarin et al. (1980). Betaine supplementation did, however, result in a reduction in the accumulation of homocysteine in the plasma of $\mathrm{N}_{2} \mathrm{O}$-exposed animals.

A number of changes in plasma amino acid concentration was observed in the various groups of animals studied. The interpretation of these amino acid changes is difficult because of the many factors which influence amino acid concentrations (Fürst, 1983). While changes due to diurnal variations were avoided by sampling at similar times of day, physical activity, previous nutrition (especially in impaired animals), age and sex were not or could not be controlled. This may explain some of the group differences in amino acid composition that were observed.

Several amino acids are metabolized via reactions requiring tetrahydrofolate (Das \& Herbert, 1976). Plasma serine was significantly increased in the $\mathrm{N}_{2} \mathrm{O}$ group compared with controls. Deacon et al. (1981) also found a rise in plasma serine levels in $\mathrm{N}_{2} \mathrm{O}$-exposed rats. In the present study, plasma histidine levels were somewhat higher in the $\mathrm{N}_{2} \mathrm{O}$ group compared with controls. These changes presumably result from decreased tetrahydrofolate and methylenetetrahydrofolate formation attendant on the $\mathrm{N}_{2} \mathrm{O}$ inhibition of the methionine synthase reaction.

The sulphur-containing amino acids methionine and cysteine serve as precursors for taurine in mammals (Peck \& Awapara, 1967). Thus the finding of a significantly-higher concentration of plasma taurine in the methionine-supplemented groups was to be expected.

Several amino acids are catabolized via the cobalamin-dependent propionic acid pathway (Chanarin, 1980). Since the mutase enzyme is known to be unaffected by exposure to $\mathrm{N}_{2} \mathrm{O}$ (Deacon et al. 1978), the increases in plasma isoleucine concentration in the $\mathrm{N}_{2} \mathrm{O}$-only group and in plasma threonine concentrations in the $\mathrm{N}_{2} \mathrm{O}$ and $\mathrm{N}_{2} \mathrm{O}$ /betaine groups may reflect the depletion of vitamin $B_{12}$ stores which accompanies long-term exposure to $\mathrm{N}_{2} \mathrm{O}$ in the bat (van der Westhuyzen et al. 1982).

Dr J. Perry of the MRC Clinical Research Centre, Harrow, England is thanked for providing the microbiological assay method. Mrs P. Theodorou is thanked for her expert technical assistance. The work was supported in part by a grant from the South African Medical Research Council.

\section{REFERENCES}

Banks, R. G. S., Henderson, R. J. \& Pratt, J. M. (1968). Journal of the Chemical Society (A), 2886-2889.

Chanarin, I. (1980). In Vitamins in Medicine, vol. 1, pp. 172-246 [B. M. Barker and D. A. Bender, editors]. London: Heinemann Medical Books.

Chanarin, I., Deacon, R., Lumb, M. \& Perry, J. (1980). Lancet ii, 505-508.

Das, K. C. \& Herbert, V. (1976). Clinics in Haematology 5, 697-725. 
Deacon, R., Jennings, P., Lumb, M., Perry, J., Purkiss, P. \& Chanarin, I. (1981). Scandinavian Journal of Haematology 27, 267-270.

Deacon, R., Lumb, M., Perry, J., Chanarin, I., Minty, B., Halsey, M. J. \& Nunn, J. F. (1978). Lancet, ii, $1023-1024$.

Deacon, R., Lumb, M., Perry, J., Chanarin, I., Minty, B., Halsey, M. J. \& Nunn, J. F. (1980). European Journal of Biochemistry 104, 419-422.

Fürst, P. (1983). Proceedings of the Nutrition Society 42, 451-462.

Kondo, H., Osborne, M. L., Kolhouse, J. F., Binder, M. J., Podell, E. R., Utley, C. S., Abrams, R. S. \& Allen, R. H. (1981). Journal of Clinical Investigation 67, 1270-1283.

Lee, P. L. Y. (1974). Biochemical Medicine 10, 107-121.

Lumb, M., Sharer, N., Deacon, R., Jennings, P., Purkiss, P., Perry, J. \& Chanarin, I. (1983). Biochimica et Biophysica Acta 756, 354-359.

Peck, E. J. \& Awapara, J. (1967). Biochimica et Biophysica Acta 141, 499-506.

Scott, J. M., Dinn, J., Wilson, P. \& Weir, D. G. (1981). Lancet ii, 334-337.

Sturman, J. A., Gaull, G. E. \& Niemann, W. H. (1976). Journal of Neurochemistry 27, 425-431.

van der Westhuyzen, J., Cantrill,R. C., Fernandes-Costa, F. \& Metz, J. (1983). Journal of Nutrition 113, $531-537$.

van der Westhuyzen, J., Fernandes-Costa, F. \& Metz, J. (1982). Life Sciences 31, 2001-2010.

van der Westhuyzen, J. \& Metz, J. (1984). Journal of Nutrition 114, 1106-1111. 